\title{
Metonymi hos Proust ${ }^{1}$
}

Den metaforiske relation, hvis grundlag er analogien, er så betydningsfuld hos Proust, så manifest til stede i hjertet af hans teori og hans æstetiske praksis såvel som i hans åndelige erfaring, at man helt naturligt føres til, som han selv blev det, at overvurdere dens betydning på bekostning af andre semantiske relationer. Det er uden tvivl Stephen Ullmann, som det tilfalder fortjenesten af, i to kapitler (V og VI) af sin bog Le Style dans le roman français, at have afsløret tilstedeværelsen i den proustske »billedverden« af ved siden af de navnkundige metaforer - nogle typisk metonymiske forskydninger, nemlig dem, der - som han siger - bygger på »kontiguiteten af to følelser, på deres samtidige tilstedeværelse i den samme mentale kontekst «, og hvorpå han som eksempel henviser til hypallager som »hårenes brune tørhed « for de brune hårs tørhed, eller, mere subtilt, »den aszurblå overflade» for den stilhed, som hersker under søndagshimlen i Combray. Man kunne uden tvivl i den samme kategori indføje andre »billeder« nævnt af Ullmann så som »skovenes gyldne friskhed« eller oven i købet haveklokkens berømte, »ovale og gyldne« ringen, hvor de visuelle egenskaber, som bliver tillagt taktile og auditive sansninger, tydeligvis fremkommer ved en overførsel fra årsag til virkning. ${ }^{3}$

1. Fraværet af den bestemte artikel i Metonymi indeholder en mening, som det måske vil være passende at røbe: det drejer sig rigtigt nok her om et egennavn, og man ser straks af hvilken slags. Man siger 'Metonymi hos Proust' som man ville sige 'Polymni hos Pindar' eller 'Clio hos Tacitus', eller rettere 'Polymni hos Tacitus' og 'Clio hos Pindar', for så vidt som en gudinde ville kunne tage fejl af døren: blot en visit, men dog ikke uden konsekvens.

2. Style in the French Novel, Cambridge 1957, p. 197. Cf. sammes The Image in the modern French Novel, Cambridge 1960 og "L'Image littéraire«, in Langue et Littérature (1961). Se videre p. 63 , note 2 .

3. Andre metonymiske hypallager, i sidste ende lige så klassiske som det skyldige papir hos Boileau: bjældens rustrøde lyd (I, 14), den flittige frugtgelé (I, 49), sengetæppets mellemste duft (I, 50), klokkernes gyldne lyd (III, 83), den fromme krusning på madeleinekagen (I, 47), der har form som en jakobsmusling.

Vi vil dog ikke presse kærligheden til metonymien så langt som til at følge George Paintre i dette mildest talt paradoksale forsvar for Léonies pande»hvirvler«: »Proust bruger, klogt og dristigt, en stilfigur ved navn metonymi; han kalder tante Léonies pandeben hvirvler for at antyde, at de ligner hvirvler (I, 52)«, Marcel Proust. Les Années de maturité, p. 236. Hvis dette faktisk er Prousts intention (men det kan man være i tvivl om), er denne "stilfigur« en ren metafor. [Sidehenvisningerne til Proust gælder her som senere Pléiadetrebindsudgaven $\dot{A}$ la recherche du temps perdu, Paris 1954, ed. Pierre Clarac et Andre Ferré. Alle Proust-citater oversættes fra Genettes citater. O.a.] 
De rent metonymiske forskydninger forbliver imidlertid ret sjældne i Prousts forfatterskab, og især gælder det, at ingen af dem i praksis bliver opfattet sådan af læseren: ringningen er uden tvivl kun oval og gylden, fordi klokken selv er det, men her som andre steder indebærer forklaringen ingen forståelse; hvad der end er dens oprindelse, går prædikatet oval eller gylden på ringningen, og ved en næsten uundgåelig sammenblanding tolkes denne egenskab ikke som en overførsel, men som en "synæstesi«: den metonymiske glidning er ikke blot »forklædt«, men faktisk transformeret til en metaforisk prædikation. Langt fra at være antagonistiske og uforenelige støtter metafor og metonymi sig til hinanden og fortolker hinanden, og at give sidstnævne, hvad der tilkommer den, skal ikke bestå i at opstille en konkurrerende liste herover som modstykke til listen over metaforer, men snarere $i$ at vise tilstedeværelsen og virkningen af »co-eksistens«-forhold inden for den samme analogirelation: metonymiens rolle inde $i$ metaforen.

Lad os ufortøvet se på to passager fra $\grave{A}$ la Recherche du temps perdu. Den første hører til i Du Côté de chez Swann: fortælleren betragter Méséglise-sletten, der helt ud i horisonten er dækket af hvedemarker, der bevæger sig i vinden; "til højre«, tilføjer han, "øjnede man man over hveden SaintAndré-des-champs' to rustikke klokketårne i huggede sten, selv slanke, skællede, feltinddelte, guillocherede, gulnende og grynede, som to aks.«Den anden findes i Sodome et Gomorrhe, under det andet ophold i Balbec; Marcel har netop sammen med Albertine besøgt kirken i Marcouville, og i en forudgribelse fremmaner han den i Saint-Mars-le-Vêtu, hvor de sammen vil begive sig hen næste dag:

"Saint-Mars, hvis to antikke, rosa laksefarvede klokketårne, på disse brændende varme tidspunkter, hvor man kun tænkte på at bade, med deres rombeformede, svagt krummede og ligesom sitrende tagsten så ud som aflange fisk, skællede, mosgroede og røde, der, uden tilsyneladende at bevæge sig, steg op af transparent og blåt vand. «

Her er således to par klokketårne, der tydeligt nok i høj grad ligner hinanden i deres grundlæggende objektive karakteristika: den langagtige eller slanke form, den gulrøde farve, den ru overflade, skællet eller hullet. Hvorfor poder fortællerens forestillingsverden ud fra disse sensorisk identiske kendsgerninger to sammenligninger, der er helt forskellige, det ene sted mellem klokketårne og aks, det andet sted mellem (de samme) klokketårne og fisk? Grunden dertil er ret åbenlys, og for så vidt angår det andet eksempel angiver Proust den i øvrigt selv meget klart i denne indskudte sætning med

4. I, p. 146 og II, p. 1015. 
kausal betydning: "på disse brændende varme tidspunkter, hvor man kun tænkte på at bade«; det er tanken om badet, havets (spatiale, temporale, psykologiske) nærhed, som drejer det metaforiske forestillingsarbejde mod en vandpræget tolkning. I Swann-teksten er forklaringen mere diskret, men ligeledes uden tvetydighed: „de to klokketårne, selv slanke« $;{ }^{5}$ Saint-Andrés klokketårne er her som to aks blandt andre, og det er omgivelserne, der antyder ligheden. Som antyder: det vil sige ikke som har skabt den, men som har udvalgt den og aktualiserer den blandt de forskellige analoge muligheder, der er indeholdt i klokketårnenes udseende; men denne virkning er tilstrækkelig til at vise indflydelsen fra kontiguitetsrelationerne på den metaforiske relation. Man ser andetsteds (I, p. 184) den samme Saint-Andrékirke vise sig midt i hveden »landlig og gylden som en høstak«; farvemotivet er det samme, men fra akset til høstakken afviger formen mærkbart: hvad der er det vigtige for Proust, er at at assimilere Saint-André i dens landlige "miljø«; aks, høstak, alt, hvad der motiverer sammenstillingen, har han gavn af.

Et langagtigt klokketårn, der er gult og guillocheret, kan således fremkalde bl.a. billedet både - og begge dele ad libitum - af et modent aks (eller en høstak) og af en gylden fisk. Mellem disse to mulige »ligheder» vælger Proust i hvert tilfælde den, som passer bedst til situationen eller (hvilket er det samme) til konteksten: Méséglises jordegenskaber, Balbecs essens af hav. Et andet klokketårn (måske det samme), det på Saint-Hilaire i Combray, fremviser i øvrigt over tre gange en forekomst af mimetisme, der er helt lignende: „En tåget efterårsmorgen kunne det, idet det rejste sig over vinmarkernes stormfulde violet, være som en purpurruin af næsten samme farve som jomfruvin«; og to sider længere fremme:

"Når man efter messen gik ind for at bede Theodor om at medbringe en brioche, der var større end sædvanligt ... havde man foran sig klokketårnet, der - gyldent og selv bagt ligesom en endnu større, indviet brioche, med skæl og klæbrige dråbedannelser, som solen havde fremkaldt - stak sin spids op i den blå himmel. $\mathrm{Og}$ om aftenen, når jeg vendte hjem fra spadsereturen og tænkte på det øjeblik, hvor jeg straks måtte sige godnat til min mor og ikke mere se hende, var det til gengæld så blødt i det forsvindende dagslys, at det så ud, som om det var blevet anbragt der og som en brun velourpude presset ind i den blege himmel, der havde givet

5. En sammenlignelig formulering, I, p. 84: Marcel har netop fremkaldt forestillingen om havehuset, hvor han søger tilflugt for at læse, og han tilføjer: „Var min tankeverden ikke også som et andet fletværk, i bunden af hvilket ... «(vores kursivering). 
efter for presset, havde ladet sig udhule ganske let for at give det plads og nu flød ud over sine kanter. $\ll^{6}$

Aks-klokketårn (eller høstak-kirke) på marken, fiske-klokketårn ved vandet, et purpurfarvet klokketårn over vinmarkerne, brioche-klokketårn i bagetiden, pude-klokketårn, når natten falder på - der er tydeligt nok hos Proust et slags tilbagevendende, næsten stereotypt stilistisk skema, som man kunne kalde toposet kamceleonklokketårnet. Umiddelbart efter det sidste eksempel nævner Proust - paradoksalt nok - tilfældet med en »en by i Normandiet, der er nabo til Balbec«, hvor kirkens gotiske spir skyder op i et perspektiv oven over facaden på de to 1700-tals palæer, hvis facader det afslutter, men

"på en måde så forskellig, så udsøgt, så ringformet, så rosafarvet, så lakeret, at man udmærket ser, at den kun er den del af to smukke, indbyrdes forenede rullesten, mellem hvilke den er kommet til at ligge på stranden, spiret, der er purpurfarvet og kamtakket med konkylier som tendannede og emaljerede hjørnetårne. $\ll^{7}$

Man ser her, at selv forskellen indskriver sig i et et lighedssystem i kraft af afsmitning: kontrasten mellem spiret og facaderne kan sammenlignes med kontrasten lige i nærheden mellem konkylien og strandstenene, og homologien kompenserer og opvejer kontrasten. I en tidligere version ${ }^{8}$ er den by i Normandiet, som her bliver fremmanet, Falaise, og det er det særlige tag på et palæ, som kiler sig ind mellem de to spir »ligesom på en strand i Normandiet en sten mellem to gennemhullede konkylier«. Variationerne i det "beskrevne« objekt neden under dette stilistiske skemas permanens viser, hvor lidt referenten betyder, og således hvor grundlæggende ikke-realistisk, Prousts beskrivelse er.

I alle disse tilfælde styrer eller garanterer nærheden ligheden, i alle disse eksempler finder metaforen sin støtte og sin motivation i en metonymi: ${ }^{9}$ således sker det forholdsvis ofte hos Proust, som om rigtigheden i en analogisering, d.v.s. graden af ligheden mellem de to termer, betyder mere for ham end dens autenticitet, ${ }^{10}$ idet vi herved forstår dens trofasthed i forhold til de

6. I, p. 63 og 65 .

7. I, p. 66; "d'une manière..« (på en måde) er muligvis en sætterfejl for "d'une matière« (af et materiale).

8. Proust: Contre Sainte-Beuve, éd. Fallois, Paris 1954, p.275.

9. I virkeligheden er motivationen gensidig og spiller med i de to betydninger: nærheden gyldiggør ligheden, som ellers ville kunne virke umotiveret eller påtvunget, men til gengæld retfærdiggør ligheden nærheden, som ellers ville kunne forekomme tilfældig og arbitrær, medmindre man da skulle antage (hvad man ikke skal), at Proust simpelt hen beskriver et landskab, som han har "for sine øjne». 
rumligt-temporale naborelationer; ${ }^{11}$ eller snarere, som om den førstnævnte forekom ham garanteret af den sidstnævnte, idet genstandene i verden forekommer at gruppere sig efter affiniteter ud fra det princip, som allerede blev påberåbt af Jean Ricardou i forbindelse med de metonymisk-metaforiske sammenfald hos Edgar A. Poe: ${ }^{12}$ det, som ligner hinanden, finder sammen ( og omvendt); således anstrenger visse kokke sig for passe en given egnsret sammen med en sauce eller en garniture, der i streng forstand har samme oprindelse, og at ledsage den af "vin de pays«, idet de er overbeviste om, at de stemmer overens, om den smagsmæssige harmoni mellem produkter fra den samme jordbund. Er det ikke den samme respekt for »konteksten«, som fører Marcel til i Balbec »kun at lade (sine) blikke falde på (sit) bord de dage, hvor der blev serveret nogle meget store fisk«, eller videre kun at ville se Tizian'er eller Carpaccio'erne i Venedig i deres "naturlige« sammenhæng og ikke transplanteret til en sal på Louvre ${ }^{13}$ eller tilmed på Méséglises marker kun at begære en bondepige fra omegnen og på Balbecs sandede strande kun en fiskerpige?

"Den forbipasserende pige, som vakte mit begær, forekom mig ikke at være et tilfældigt eksemplar af den generelle type: kvinden, men et nødvendigt og naturligt produkt af denne jordbund - jorden og de levende væsener adskilte jeg ikke fra hinanden. Jeg begærede en bondepige fra Méséglise eller fra Roussainville, en fiskerpige fra Balbec, på samme måde som jeg begærede Méséglise og Balbec. Den glæde, som de kunne give mig, ville have forekommet mig mindre sand, jeg havde ikke troet på den, hvis jeg efter eget behag havde ændret vilkårene. I Paris at kende en fiskerpige fra Balbec eller en bondepige fra Méséglise ville have været som at modtage konkylier, jeg ikke havde set på stranden, eller en bregne, som jeg ikke havde fundet i skoven, det ville have været at

10. Distinktionen mellem disse to egenskaber bliver ikke altid klart opfattet, og det retoriske metasprog afspejler og opretholder denne forvirring: for eksempel foreskev de klassiske teoretikere ikke at "trække metaforen for langt«, ikke at lade den vedrøre en "for fjern lighed «; omvendt anbefaler Breton i Les Vases communicants at »sammenligne to objekter så langt fra hinanden som muligt«: hverken de første eller den anden siger (måske ved de det heller ikke), hvorvidt »fjernheden«, som de taler om, er et mål for afstanden, som skiller genstandene, eller for deres grad af lighed. En passage i Figures, p. 249, tager stadig del i den samme forvirring.

11. Det rumlige tema forekommer faktisk næsten altid dominerende, men der er rettelig intet, der forbyder en metonymisk forbindelse, som er rent temporal, ligesom i denne sammenligning motiveret af en datos nærhed: "Disse buskadser, som jeg havde set i haven, havde jeg ikke, idet jeg antog dem for fremmede guder, taget fejl ligesom Magdalene, da hun i en anden have en dag, hvis årsdag snart ville komme, så en menneskelige skikkelse og troede, at det var gartneren?«(II, p. 160).

12. "L'or du Scarabée«, in Tel Quel 34, p. 47.

13. I, pp. 694, 440-441. 
beskære den glæde, som kvinden gav mig alt det af, som min fantasi havde indhyllet hende i. Men således at strejfe omkring i Roussainvilleskovene uden en bondepige, man kunne omfavne, det var ikke at kende disse skoves skjulte skat, deres dybe skønhed. Denne pige, som jeg kun så oversået med blade, hun var for mig i sig selv som en lokal vækst blot af en mere ophøjet art end de andre og med en struktur, der tillod en endnu tættere end hos de andre at lære egnens dybe smag at kende. $\mathbb{1}^{14}$

Man opdager her på sin vis analogiens fødsel i netop det øjeblik, hvor denne frigør sig fra den helt fysiske nærhed, hvorfra den ser dagens lys: den unge bondepige ses (forestilles) »oversået med blade«, før ( og med det formål at) hun selv bliver "som en vækst«. Ingen anden tekst illustrerer uden tvivl bedre den stedsfetichisme, som fortælleren senere afsværger som en ungdomsforsyndelse og en "illusion at miste«, men som uden tvivl ikke desto mindre er en første forudsætning for den proustske sensibilitet: en af disse første forudsætninger, $i$ modsæetning til hvilke hans sidste tankegang opstår.

Intet inkarnerer helt sikkert bedre denne blandede tilstand af lighed og nærhed end familierelationen, og man ved, med hvilken forkærlighed Proust udnyttede denne privilegerede situation, ved at nærme tanten og nevøen til hinanden, ved at erstatte sønnen med faderen og datteren med moderen, idet han pressede den tvetydige fornøjelse ved forvirringen til det svimlende. Man ville udmærket kunne sige, at beskrivelsens kunst for ham består i mellem genstandene i verden at afsløre sådanne ligheder ved hjælp af virkelige slægtskaber; bemærk med hvilken tilfredshed han giver sig til at sammenholde portrættet og modellen, Elstirs søstykker over for landskabet ved Balbec eller Saint-Andrés rustikke skulpturer med den lighed, som bliver "attesteret« af jævnføringen med en ung bondepige fra Méséglise, der er kommet for at søge ly, en levende kopi, »hvis nærvær, ligesom murbevoksningens blade, der skød op ved siden af murværkets bladornamenter, syntes bestemt til ved en direkte konfrontation med naturen at sætte en i stand til at fælde en dom om kunstværkets sandhed. $\aleph^{15}$ Denne konfrontation mellem det ens finder naturligvis sin reneste og mest perfekte form i scenen, der bliver fordoblet i genstanden og dens refleks, sådan som Proust organiserer det i en usædvanlig sofistikereret iscenesættelse i Marcels værelse på Grand Hotel i Balbec, hvor væggene, takket være en dekoratør sendt af forsynet, var dækkede af bogskabe med glasruder, hvori havets og himlens skiftende sceneri reflekteredes så tydeligt, »idet de oprullede en frise af klare havbilleder, som kun blev afbrudt af mahognifyldningerne», at disse sammen-

14. I, p. 156-57.

15. I, p. 152. 
byggede bogskabe i visse øjeblikke, »idet de fremviste skyer af samme slags blot $\mathrm{i}$ en anden del af horisonten og anderledes farvet af lyset, syntes at tilbyde en gentagelse, som visse moderne mestre holdt af, af en og samme virkning, fastholdt på hele tiden forskellige tidspunkter, men som nu med kunstens ubevægelighed alle kunne ses samlet i ét værk, udført i pastel og indrammet i glas«. Det er en mangfoldiggørelse af landskabet, som åbenlyst er euforisk, ikke blot fordi den transformerer natursceneriet til en kunstvirkning, men også, og omvendt, fordi værket, der her bliver efterlignet, ligesom Elstirs marinebilleder, som det er et ekko af, bliver forenet med sin kontekst: Proust sammenligner værelset i Balbec med »en af disse soveværelsesmodeller, som man præsenterer på udstillingerne af møbler i "modern style«, hvor de er udsmykket med kunstværker, som man har antaget ville være i stand til at fornøje øjet hos den, der skal sove der, og hvortil man har valgt motiver med relation til den slags beliggenhed, beboelsen bør have«, ${ }^{16}$ og det er manifest, at nydelsen ved scenen relaterer sig netop til denne harmoniske relation. $^{17}$

Eksemplerne på metaforer med metonymisk fundament, eller diegeti$s k e^{18}$ metaforer, er naturligvis spredt over hele Recherche, og det ville være kedsommeligt og unødvendigt at foretage en udtømmende optælling af dem. Lad os imidlertid til illustration anføre hertuginden af Guermantes blik i kirken i Combray, »blåt som en solstråle, der kunne have passeret glasmaleriet af Gilbert den Onde« - hvilket glasmaleri netop er det, der smykker det kapel, som hertuginden altså opholder sig i. ${ }^{19}$ Eller denne hvælving og

16. I, p. $383,805,383$.

17. "Hvorfor ... skulle man ikke beskrive ... de steder, hvor man arrangerede mødet med denne sandhed?... Undertiden var der en slags harmoni mellem landskabet og ideen«, Hæfte 26, fol.18, citeret af Bardeche i Marcel Proust Romancier, Paris 1971, p. 264; vores kursivering.

18. Termen er lånt hos filmsprogsteoretikerne: diegetiske metaforer $\mathrm{i}$ den betydning, at deres »vehikel« er hentet fra diegesen, d.v.s. fra fortællingens spatialt-temporale univers. (Hitchcock beskriver selv et smukt eksempel herpå taget fra North by Northwest: "Når Cary Grant lægger sig hen over Eve Marie Saint i sovevognen, hvad gør jeg så? Jeg viser toget, der opsluges i en tunnel. Det er helt klart et symbol«, L'Express, 16.3.1970.) Brugen af denne term bør for det første ikke skjule, at selve fænomenet metafor, eller sammenligningen, ligesom enhver figur, i sig selv repræsenterer en »extradiegetisk« intervention fra »forfatterens " side; endvidere at en metafors vehikel i realiteten ikke i nogen absolut forstand er diegetisk eller ikke-diegetisk, men altid afhængig af forekomsterne mere eller mindre diegetisk: lidenskabens flammer er som bekendt mere diegetiske for Pyrrhus i Andromaque end for den almindelige dødelige; en metonymis vehikel er altid pr. definition stærkt diegetisk, og det er uden tvivl det, som gør den fortjent til yndest i den klassiske æstetik. Man vil klart opfatte forskellen ved at sammenligne de diegetiske situationer i de to figurative vehikler i Saint-Amants halvvers (der allerede er analyseret andetsteds): guldet falder for jernet. Metonymet jern (for segl) er ubetvivleligt diegetisk, eftersom jernet er til stede i seglet; det metaforiske vehikel guld (for hvede) er groft sagt ikke-diegetisk, men mere præcist bør man sige, at det er diegetisk i forhold til guldets (aktive) tilstedeværelse i diegesen. Som et perfekt eksempel på den diegetiske metafor er den sidste strofe i Booz endormi, hvor det metaforiske materiale (Gud er høstkarl, månen segl, marken er stjernerne) helt tydeligt stammer fra situationen. 
denne baggrund af kalkmalerier af Giotto i Arena-kapellet i Padua "så blå at det synes, som om den strålende dag var trådt ind over dørtærsklen sammen med den besøgende, og for et øjeblik var kommet til at sætte sin rene himmel i skyggen og til afkøling, sin rene himmel, som knap nok blev en smule mere formørket over at være blevet befriet for sine forgyldninger fra lyset, ligesom i disse korte pauser, som afbryder de smukkeste dage, når - uden at man har set en sky, og idet solen for et øjeblik har vendt sit blik andetsteds hen - det azurblå formørkes endnu mere blidt $\aleph^{20}$ (som man allerede havde kunnet gøre i den ovenfor citerede passage om Saint-André-des-Champs, bemærker man her fordoblingen af processen, ved at der i den første sammenligning kun let forskudt er indsat en anden ${ }^{21}$ ); endvidere det langt mere komplekse netværk af analogier og nærhedsrelationer, som bindes sammen i denne anden passage fra la Fugitive, hvor fortælleren genkalder sine besøg i Sankt Markuskirkens dåbskapel sammen med sin mor:

»der er kommet et tidspunkt for mig, hvor det - når jeg erindrer mig dåbskapellet foran Jordans bølger, hvori Johannes neddykker Kristus, mens gondolen ventede os foran Piazettaen - ikke mere er mig ligegyldigt, at der ved siden af mig i denne kølige halvskygge var en kvinde draperet $\mathrm{i}$ sin sørgedragt med den ældre kvindes respektfulde og entusiastiske inderlighed, som man ser på Carpaccios Skt. Ursula $i$ Venedig, og at denne kvinde med røde kinder og sørgmodige øjne hyldet i sine sorte slør var min moder, og at intet mere for mig vil kunne slippe ud af dette blidt oplyste allerhelligste i Sankt Markus, hvor jeg er sikker på at genfinde det, fordi det der har sin faste plads som en mosaik «:22

dåbsmosaikken, »i forbindelse med beliggenheden«, hvor Jordanfloden fremtræder som et andet dåbskapel en abyme inden for det første; det modstykke til Jordanflodens bølger, som bølgerne i lagunen foran Piazettaen giver, den iskolde friskhed, der falder på de besøgende som dåbsvand, den sørgende kvinde magen til hende, man lige ved siden af ser på Carpaccios maleri, der selv en abyme er et billede af Venedig i Venedig, ${ }^{23}$ moderbilledets hellige ubevægelighed i erindringen om »det allerhelligste«, ligesom en af de

19. I, p. 177. Man finder en effekt at samme slags, også her i forbindelse med Oriane, II, p. 741, hvor hertuginden siddende under et maritimt vægtæppe gennem afsmitning bliver »som en vandgudinde .

20. III, p. 648 .

21. Dette er en effekt, som er blevet undersøgt af Spitzer (i Études de style, Paris 1970, p. 459) og af Ullmann i »L'Image littéraire«, p. 47.

22. III, p. 646 .

23. Se umiddelbart efter denne passage beskrivelsen af et Carpacciobillede omtalt som et virkeligt veneziansk landskab. 
mosaikker, der befinder sig foran ham, og ligeledes antydningen af en analogi mellem fortællerens og Kristi moder. Men det mest spektakulære eksempel er åbenlyst Sodome et Gomorrhe I, dette stykke på tredive sider, der helt er opbygget på parallellen mellem »forbindelsen Jupien-Charlus« og en humlebis befrugtning af hertugindens orkidé: en parallel, som omhyggeligt er forberedt, arrangeret, holdt i gang, aktiveret igen side efter side hele vejen igennem episoden ( og i den kommentering, den giver anledning til), og hvis symbolske funktion ikke ophører med at næres, om man så må sige, af kontiguitetsrelationen, som er etableret i kraft af gården i Guermantes palæ (stedets enhed) i det øjeblik, hvor insektet og baronen unisont summende bevægede sig derind (tidens enhed); det er således ikke tilstrækkeligt, at det mirakuløse (eller i det mindste af heltene anses for at være det) møde mellem de to homoseksuelle er »ligesom« det mirakuløse møde mellem en orkidé og en humlebi, at Charlus kommer ind »idet han fløjter som en humlebi«, at Jupien "står stille« under hans blik og "slår rod som en plante« etc.: det er også nødvendigt, at de to møder skal finde sted »i samme øjeblik», og på samme sted, idet analogien således kun fremtræder som en slags sekundær, og måske illusorisk, effekt af samtidigheden. ${ }^{24}$ I denne bestræbelse på ved hjælp af disse net at komponere en stedets enhed, et »tidspunkts« harmoni, en klimatisk enhed, synes der i Recherche du temps perdu at eksistere nogle mere intense koncentrations- eller krystallisationspunkter, som korresponderer med de brændpunkter, hvorfra der foregår en æstetisk udstråling. Man ved, i hvor høj grad visse personer henter deres personlige tema fra den samklang med deres fædrene egn, som de opretholder (Oriane med Guermantes-fødestedet) eller rammen om deres første fremtræden (Albertine og hendes kammeratgruppe i silhuet foran havet), ${ }^{25}$ Saint-Loup i solskinnets strålende hvidhed, der bliver multipliceret af de stråler, der springer fra

24. I det mindste hvis man placerer sig inde i den situation, som er konstitueret af teksten (fiktiv eller ikke). Omvendt er det tilstrækkeligt at placere sig uden for teksten (foran den) for at man lige så vel kan sige, at samtidigheden er blevet tilvejebragt for at motivere metaforen. Kun en situation, som kan anses for at være dikteret forfatteren af historien eller af traditionen og således (af samme grund) for nonfiktiv (eksempelvis "Booz endormi«), påtvinger læseren en hypotese om en (genetisk) kausalkæde: metonymiårsag $\rightarrow$ metafor-virkning, og ikke om en formålskæde: metafor-mål $\rightarrow$ metonymi-middel (og således, ud fra en anden kausalitet, metafor-årsag $\rightarrow$ metonymi-virkning), som altid er mulig i en fiktion, der hypotetisk er ren. Det giver sig selv, at hos Proust kan ethvert eksempel på dette niveau rejse en uendelig diskussion mellem en læsning af Recherche som fiktion og en læsning af Recherche som selvbiografi. Måske er det i øvrigt nødvendigt at forblive inde $i$ denne svingdør.

25. I, pp. 788, 823, 944, 947. Denne oprindelige situation fører en hel række af maritime sammenligninger med sig, mellem gruppen og en kæde af måger (p. 788), en stjernekoral (p. 823-24 og 855), en bølge (p. 855); Albertine er omskiftelig som havet (pp. 947-948); i La Prisonnière endelig er den søvn, omplantet til Paris, - »om bord på hvilken« Marcel drømmer - blid "som en vestenvind fra havet« (III, p. 70). 
hans monokel; omvendt kan en persons dominerende æstetik i heltens drømmeri fremkalde billedet af den tilhørende lokalitet: således antyder $\mathbf{M}^{\text {lle }}$ de Stermarias "sølv- og rosenteint« (hvormed hendes uforanderlige grå filthat »harmonerer«) romantiske spadsereture for to »i skumringen, hvor lyngplanternes rosa blomster skinnede blidere hen over vandet, der var blevet mørkt« ${ }^{26}$ Men det er måske »omkring $\mathbf{M}^{\text {me }}$ Swann«, på de sidste sider af Swann og første del af Jeunes Filles en fleurs, som bærer netop den titel, at denne kilde til kromatisk harmoni manifesterer sig mest insisterende (en insisteren, som måske er en smule for mærkbar, og i den henseende fint i overensstemmelse med den ny Odettes energiske og demonstrative æsteticisme: "orangefarvede blus«, "røde ild«, »krysantemernes rosa og hvide flamme i novemberskumringen«; "symfoni i hvid dur" af buketter af snebolde og hermelinspelse, »der så ud som vinterens sidste sneflader« $\mathrm{i}$ aprils afsluttende frostperioder, ${ }^{27}$ tone på tone af hendes fremtoninger i skoven, kjole og kyse i mauve, irisblomst, violbuket, stor parasol i »den samme nuance« og vendende sig ind mod hende som "genskinnet fra et bjerg af blåregn«, toiletter, der altid var »forbundet med årstiden og tidspunktet med et uomgængeligt bånd (»blomsterne i hendes bøjelige stråhat, hendes kjoles små bånd forekom mig at være født af maj måned endnu mere naturligt end havernes og skovenes blomster«), og samtidig hendes »rolige og flanerende« fremtræden, indøvet for at »antyde nærheden« af denne lejlighed, hvis »indre skyggefuldhed og friskhed man ville kunne sige hun hele tiden førte omkring sig«: ${ }^{28}$ en serie af monokrome billeder, hvor - gennem en iscenesat "tidsfarves« mimetiske overgang - ægteskabet fuldbyrdes mellem det ydre og det indre, mellem haven og salonen, mellem det kunstige og årstiden; omkring $\mathbf{M}^{\text {me }}$ Swann udviskes alle konstraster, alle modsætninger opløses, alle skillevæggene forsvinder i det kontinuerlige rums eufori.

Man har allerede set gennem hvilken proces, på én gang mere brutal og mere subtilt kunstig (samlingen af "marinebilleder« anbragt rundt om i heltens værelse gennem landskabets refleks i bogskabets glasruder), Proust i Balbec sikrer denne harmoni mellem det indre og det ydre. Sandt at sige blev lokalitetens afsmittende virkning allerede etableret i tilstrækkelig grad gennem omtalen af murene, der var blevet bestrøget med emaljelak, og som havde "et rent udseende, azurblåt og salt, ligesom de blanke vægge i et svømmebasin, hvori vandet blåner; $\ll^{29}$ fortællerens værelse er, allerede inden det bliver invaderet af det multiplicerede havsceneri, så at sige grundlæggende

26. I, p. 869.

27. I, pp. 426, 634 .

28. I, pp. 426, 636-641.

29. I, p. 383. 
blevet maritimiseret gennem tilstedeværelsen af disse skillevægge, der er skinnende og ligesom rislende af vand. Til dette svømmebasin af et værelse, som senere bliver en skibskahyt, ${ }^{30}$ svarer et akvarium af en spisesal: „Om aftenen ... fik de elektriske kilder lyset til at vælde frem i bølger i den store spisesal, der blev som et umådeligt og eventyrligt akvarium foran glasvæggen, hvor Balbecs arbejderbefolkning, fiskerne såvel som de småborgerlige familier, usynlige i skyggen, stimlede sammen ved ruden for at få et glimt af disse folks luksusliv, der langsomt balancerede i strømhvirvler af guld, og som for de fattige var lige så usædvanligt som fiskenes og de fremmedartede bløddyrs liv. ${ }^{31}$

Man ser, at modsat det, der sker i $\mathrm{M}^{\text {me. }}$ Swanns Paris, foregår sammenblandingen af indre og ydre ikke i begge retninger: i Balbec er metaforens dominerende term næsten altid havet; der stråler overalt »havelementets kraft, ${ }^{32}$ som Proust vil sige i relation til Elstirs billeder. Det er åbenlyst dette element, som giver de to episoder i Balbec, og specielt den første af dem, deres "mangeartede og mægtige enhed«. Et kontinuerligt netværk af analogier, i det "virkelige« landskab såvel som i den billedmæssige repræsentation, stræber efter at "undertrykke enhver afgrænsning« mellem havet og alt det, som færdes i det eller grænser op til det: fiskene, som det indeholder, og som det nærer: "havet, der allerede var koldt og blåt som den fisk, der hedder multe $«{ }^{33}$ himlen, som hvælver sig over det, og som flyder sammen med det i horisonten: „takket være en effekt fra solen ... kom jeg til med glæde at se en blå og flydende zone uden at vide, om den tilhørte havet eller himlen « ${ }^{34}$ solen, som oplyser det, og som gennemtrænges af dets flydende væsen og friskhed, samtidig med at den indgyder det sit lys, "et fugtigt, hollandsk lys, hvor man følte den gennemtrængende kulde fra havet stige op til selve solen«, indtil den fuldstændige kromatiske omvending, hvor havet bliver gult »som en topas ... hvidt og mælkeagtigt som øl« og solen "grøn som vandet $\mathrm{i}$ et svømmebasin $i^{35}$ og denne havlysets flydende karakter, der som man ved

30. "Hvilken glæde ... at se havet, i vinduet og i alle bogskabenes glaslåger, ligesom i en kahyts koøjer ...«(I, p. 672); »Jeg kastede mig på min seng; og, som om jeg havde befundet mig i køjesengen på en af disse både, som jeg havde set ganske tæt på, og som man om natten forbavsedes over at se bevæge sig langsomt i mørket, ligesom dunkle og stille svaner, som dog ikke sov, var jeg på alle sider omgivet af havbilleder« (I, p. 804). Man bemærker her det explicitte sammenfald af den metaforiske relation (som om) og den metonymiske (toet på); og den anden metafor, som også er metonymisk, indføjet i den første (skibe $=$ svaner).

31. I, p. 681. Metaforen fortsætter endnu nogle linier.

32. I, p. 837.

33. I, p. 803. Sammenligningen hav-fisk bliver her umiddelbart fordoblet af en anden, komplementær sammenligning, himmel-fisk: „Himlen af den samme rosa farve, som en af de laks, som vi kort efter ville bede om at få serveret i Rivebelle».

34. I, p. 835 . Cf. p. 805 og 904 .

35. I, pp. 898, 674. Marcel vil senere i Venedig genfinde »disse solstråler, der var søgrønne« (III, p. 626) eller "grønlige« (p. 645). 
er et fællestræk for normanniske, hollandske og venezianske lokaliteter, er hos Proust som hos en van Goyen, en Guardi, en Turner eller en Monet landskabets stærkeste enhedsskabende faktor: det er eksempelvis den, som med sin patina, der er »lige så smuk som århundreders«, "forvandler» den alt for nye eller alt for restaurerede kirke i Marbouville l'Orgueilleuse: „gennem den syntes de store bas-relieffer kun at ses under et flydende lag, dels væskeagtig, dels lysende; den hellige jomfru, Skt. Elisabeth, Skt. Joachim badede stadig i uhåndgribelige hvirvler, næsten på det tørre, i flugt med vandet eller i flugt med solen « $;^{36}$ endelig jorden, hvorom man ved, hvordan Elstir ikke ophører med "tavst og utrætteligt« at sammenligne den med havet, idet han om den ene af de to, og omvendt, kun anvender »termer« lånt fra terminologien om den anden, og idet han systematisk udnytter lyseffekterne og perspektivets kunstgreb. Kort efter vil Elstir selv angive den venetianske model for disse fantasmagorier: "Man vidste ikke mere, hvor jorden holdt op, hvor vandet begyndte, hvad der endnu var palæet, og hvad der allerede var skibet «. ${ }^{37}$ Men denne model er ikke blot billedmæssig, den er lige så vel amfibielandskabets virkelighed, som trænger sig ind på den proustske maler foran havnen i Carquethuit, sådan som den andetsteds trængte sig ind på Carpaccio, Veronese eller Canaletto. Og fortælleren vil udmærket under sit andet ophold i Balbec kunne henføre sin sene opfattelse af disse analogier til indflydelsen fra den store impresssionist, af havet, der er blevet »landligt«, fiskerbådenes "støvdækkede« kølvand, der ligner landsbykirketårnene, bådene der mejer havets "snavsede« overflade, ${ }^{38}$ vi ved i virkeligheden, at allerede før han havde set Elstirs lærreder, hændte det for ham, at han »tog et af havets mørkere partier for en kyst i det fjerne«, at han dagen efter sin ankomst til Balbec fra vinduet i sit værelse opdagede, at havet lignede et bjerglandskab, og endda at han efter lang tid forestillede sig kirketårnet i Balbec som en klint, bølgerne slog imod..$^{39}$ Hvad enten de tillægges Elstir eller direkte perciperes af Marcel, illustrerer disse visuelle »metaforer«, som giver landskabet i Balbecs dets særlige tone, perfekt denne grundlæggende tendens i Prousts skrift og forestillingsverden - i »teknik« og »vision« - til sammenføjning gennem naboskab, til at projicere analogirelationen over på kontiguitetsrelationen, sådan som vi allerede har fundet den i værket $\mathrm{i}$ den unge helts stednavnedrømmerier. ${ }^{40}$ Fra disse undertiden bestikkende sammenstillinger vil vi låne et sidste eksempel

36. II, p. 1013.

37. I, p. 899.

38. II, pp. 783-84.

39. I, pp. 835, 672-3, 658 .

40. Figures II, p. 232-247. Den semantiske illusion (som vi skal huske senere bliver afsløret af Proust selv) består faktisk i at læse forbindelsen mellem signifié og signifiant som analog, skønt den kun er en konventionsbetinget forbindelse; cratylismen tolker tegnene (substantiverne) som "billeder", det vil typisk sige en metonymi som en metafor. 
fra Du Côté de chez Swann: det er genkaldelsen af de karafler, som sank ned i Vivonne,

"og som, idet de var blevet fyldt af flodvandet, som de omvendt var indesluttet i, på én gang med deres transparente sider »indeholdende« ligesom hærdet vand og samtidig selv »indeholdt«, nedsænket i en større beholder af flydende og rindende krystal, fremkaldte billedet af friskhed på en mere delikat og pirrende måde, end de ville have gjort på et opdækket bord, idet de kun viste den i flugten i denne vedvarende allitteration mellem vandet uden konsistens, hvor hænderne ikke kunne fange den, og det ikke-flydende glas, hvori ganen ikke kunne nyde den «. ${ }^{41}$

Glas = hærdet vand, vand $=$ flydende og rindende krystal, det er her ved hjælp af et typisk barokkunstgreb, at substanserne, som er i kontakt med hinanden, udveksler deres prædikater for at indtræde i denne "reciprokke metafor«-relation, ${ }^{42}$ som Proust dristigt kalder allitteration: det er en legitim dristighed, for det drejer sig ligesom i den poetiske figur rigtigt om et sammenfald af analogien og nærheden; en afslørende dristighed, for tingenes samklang er her minutiøst arrangeret som når det drejer sig om ordene i et vers, ren teksteffekt, der kulminerer lige præcist i dette selvbeskrivende, flydende og transparente syntagme: vedvarende allitteration.

Det er iøvrigt netop på disse sprogfænomeners tvetydighed, Proust ofte støtter sig for ved en rent verbal forbindelse at motivere de af hans metaforer, som ikke hviler på en "virkelig« nærhed. Man ved f.eks., at sammenligningen mellem operasalen og de undersøiske dybder i begyndelsen af Guermantes hele vejen igennem er ligesom hængt op på ordet baignoire ${ }^{43}$ (der i sig selv er en metafor i almindelig sprogbrug), som i kraft af sin dobbelte betydning sætter de to universer i direkte forbindelse med hinanden, og som alene ved at blive udtalt af en kontrollør øjeblikkeligt udløser hele metamorfosen: "Korridoren, som man viste ham efter at have udtalt ordet 'baignoire', og hvor han begav sig ind, var fugtig og revnet og forekom ham at føre til undersøiske grotter, til vandnymfernes mytologiske kongerige «. ${ }^{44}$ Men selve længden af disse effekter (i dette tilfælde seks sider) og måden, hvorpå de skridt for skridt udstrækker sig til et sigende antal objekter (vandgudinder, skæggede havguder, glatslebet rullesten, glat alge, akvariets glasvæg etc.), ender med at give læseren illusionen af en kontinuitet og således

41. I, p. 168.

42. B. Migliorini: "La Metafora reciproca«, Saggi linguistici, Firenze 1957, pp. 23-30.

43. [Ordet betyder både et badekar og en (parket- eller parterre-)loge i et teater. O.a.]

44. II, p. 38. 
en nærhed, mellem sammenlignende og sammenlignet, dér hvor der kun er en multiplikation af deres lighedspunkter og konsistens i en tekst, som synes at retfærdiggøres (bekræftes) ved selve dens udbredthed. ${ }^{45}$ Således kan man måske forklare Prousts markante interesse for fortsatte metaforer eller sammenligninger. Ret sjældne er hos ham de glimtvise forbindelser, der anslås af et enkelt ord, for hvilke den klassiske retorik udelukkende forbeholder termen metafor. Alt foregår, som om lighedsrelationen for ham altid må (skønt ofte på en ubevidst måde) hente styrke ved at støtte sig på en mere objektiv og sikrere relation: den, som i en kontinuitet i rummet - rum i verden, rum i teksten - sammenbinder de ting, der befinder sig ved siden af hinanden, og ord, som er føjet sammen.

Det er imidlertid en omvendt fremgangsmåde, som manifesterer sig i den afgørende erfaring af den ufrivillige erindring, hvorom man ved, at den for Proust udgør selve grundlaget for tilflugten til metaforen, i kraft af denne meget simple ækvivalens, ifølge hvilken metaforen i forhold til kunsten er det, som erindringsresten er i forhold til livet, en sammenstilling af to følelser gennem »en ligheds mirakel «. ${ }^{46}$ Tilsyneladende er der faktisk kun noget rent analogt i erindringsrestmekanismen, som beror på identiteten i følelser registreret på meget store afstande af hinanden i tid og/eller rum. Mellem Léonies værelse dengang og den parisiske lejlighed nu, mellem dåbskapellet i Skt. Markus for nylig og gården i Guermantes' palæ i dag, et enkelt kontakt- og kommunikationspunkt: smagen af madeleinekagen dyppet i lindete, fodens skæve position på ujævne brosten. Intet er således mere forskelligt fra de analogier anslået af en spatio-temporal nærhed, som vi indtil nu har mødt: metaforen er her tilsyneladende ubesmittet af enhver metonymi.

Den bliver ikke ved med at være det et øjeblik længere. Eller rettere, den har aldrig været det, og der skal blot et efterfølgende analysearbejde til at slå fast, at generindringen »begyndte« gennem det, som denne analyse betegner som dens »årsag«. Den virkelige oplevelse begynder ikke ved fastholdelsen af en identisk følelse, men gennem en følelse af "glæde«, af »lykke«, som først viser sig "uden forestilling om dens årsag « ${ }^{47}$ (og man ved, at bortset fra visse

45. »Rækken af afledte metaforer bekræfter gennem en gentaget anvendelse af den referentielle funktion rigtigheden i den primære metafor. Den udspundne metafor giver således læseren, som afkoder den, et voksende indtryk af rigtighed ", in Michael Riffaterre: »La métaphore filée dans la poésie surréaliste«, in Langue française, septembre 1969, p. 51. Det er i øvrigt nødvendigt at bemærke tilstedeværelsen i fyrstindens hår i episoden med operaaftenen af en genstand, som effektivt er lånt fra det underjordiske univers, og som ligesom ordet »baignoire« også fungerer som forbindelsesled mellem det sammenlignede og det sammenlignende rum: "et hårnet lavet af disse hvide muslingeskaller, som man fisker i visse australske farvande, og som var blandet med perler, en havmosaik, som lige var steget op af bølgerne« ...«, p. 41 .

46. III, p. 871.

47. I, p. 45 . 
mislykkede erfaringer så som den med Hudimesnils træer, så forbliver denne forestilling uopretteligt enkeltstående). Derefter afviger de to erfaringer i nogen grad i deres forløb: i Swann forbliver glæden uspecificeret indtil det øjeblik, hvor den sensoriske kilde er blevet identificeret: først da, men »øjeblikkeligt«, udvider den sig med en hel række af forbundne sansninger, fra koppen med lindete til værelset, fra værelset til huset, fra huset til landsbyen og til hele den omliggende »egn«; i le Temps retrouvé bærer følelsen af »lykke« lige fra starten i sig selv en sensorisk specifik karakter, af »billeder, der er blevet kaldt frem«, dybt azurblå, friskhed, lys, som kendetegner Venedig, allerede før den ensartede følelse ville kunne lokaliseres; og det bliver det samme med erindringen om togstoppet, der umiddelbart er udstyret med attributter (lugten af røg, skovens friskhed), som i høj grad overskrider grænserne for den skjulte forbindelse mellem de to lyde; og endelig gælder det for synet af Balbec (saltagtigt azurblå, svulmet op til blålige bryster) fremkaldt af kontakten med den stivede serviet og for det (Balbec ved aftentide), som en lyd fra vandledningen foranlediger. Man ser således, at den metaforiske relation aldrig er blevet perciperet først, og at den oven i købet oftest først dukker op i slutningen af oplevelsen som nøglen til et mysterium, der hele vejen igennem har udspillet sig uden den.

Men hvilket moment det end er, hvor den rolle manifesterer sig, som spilles af det, man sagtens kunne kalde den analoge detonator (eftersom Proust selv taler om »erindringseksplosionen ${ }^{48}$ ), er det væsentlige at notere, at denne første eksplosion hver gang ledsages, nødvendigvis og med det samme, af en slags kædereaktion, som fortsætter, ikke mere gennem analogi, men gennem kontiguitet, og som meget præcist er det moment, hvor den metonymiske afsmitning (eller, for at bruges Prousts egen term: udstråling ${ }^{49}$ ) afløser den metaforiske erindringsfremkaldelse. »Prousts interesse for de sensoriske indtryk, « skriver Ullmann, »begrænsede sig ikke til deres indre kvaliteter og til de analogier, som de antydede: han var ligeledes fascineret af deres evne til at fremkalde andre sansninger og af hele den oplevelseskontekst, hvortil de var knyttet. Heraf betydningsfuldheden af sanseoplevelser i den ufrivillige erindringsproces. ${ }^{50}$ Måden, hvorpå "oplevelseskonteksten" ved navn Combray, Balbec eller Venedig bliver fremkaldt med afsæt i en uendelig lille sansning - »en lille, næsten umærkelig dråbe«, der uden at give efter bærer »erindringens uendelige bygningsværk» - er tilstrækkelig til at bekræfte denne observation. Lad os tilføje, at Proust selv, skønt han giver indtryk af kun at fastholde oplevelsens metaforiske moment (måske fordi det

48. III, p. 692.

49. "Der havde været inden i mig, udstrålende en lille zone omkring mig, en følelse ...«, III, p. 873.

50. Style in the French Novel, p. 197. 
moment er det eneste, som han kan benæevne), gentagne gange insisterer på betydningen af denne udvidelse gennem nærhed. »I det tilfælde som i alle de forudgående«, siger han i relation til sidste oplevelse, „forsøgte det fælles sanseindtryk at genskabe det gamle sted omkring sig ... Det sted, som for længe siden var blevet frembragt omkring det fælles sanseindtryk ... Disse fortidens genopstandelser er så totale at de ikke kun lægger beslag på vores øjne ... de tvinger sig ind i vore næsebor ... vores vilje ... vores person i sin helhed ...«Han kommer lidt efter tilbage til det for at gentage, at ikke blot synet af havet, men duften af værelset, vindens hastighed, længslen efter frokost, uvisheden mellem forskellige spadsereture, alt det (som i sin helhed er Balbec) er »knyttet til sansningen af linned« (i den stive serviet), og han tilføjer, på en måde, som er endnu mere værdifuld i forhold til vores sigte, at »højdeforskellen mellem de to brosten havde forlaenget de indtørrede og sparsomme billeder, som jeg havde af Venedig, $i$ alle retninger og alle dimensioner, af alle de sanseindtryk, som jeg havde følt, idet de sammenkødede pladsen med kirken, kanalen med anløbsbroen, og med alt det, som øjnene ser, der i begærets verden kun ser det, som bliver set af sjælen. $\ll^{51} \mathrm{Lad}$ os endelig erindre om måden, hvorpå de forskellige elementer i omgivelserne i Combray »lægger sig«til hinanden - pavillonen, huset, landsbyen, pladsen, vejene, parken, Vivionne, kirken og de gode mennesker. Selv om den indledende "lille dråbe« $\mathrm{i}$ den ufrivillige erindring ganske vist er af metaforisk karakter, så er »erindringens bygningsværk« helt igennem metonymisk. Og lad det være sagt i forbifarten, at der er fuldstændig lige så meget »mirakel«i den anden form for association som i den første, og at man skal have en særlig "analogistisk « forudindtagethed, før man i den grad lader sig betage af den ene og i så ringe grad af den anden. Lad os således så småt vende staven i den anden retning: det sande proustske mirakel er ikke, at en madeleinekage dyppet $\mathrm{i}$ te har samme smag som en anden madeleinekage dyppet i te, og som derved genopvækker erindringen; det er snarere, at denne anden madeleinekage med sig får et værelse til at genopstå, et hus, en hel landsby, og at dette gamle sted, i et sekund, kan »ryste grundvolden« på det aktuelle sted, trænge gennem dets døre og få dets møbler til at vakle. For det forholder sig sådan, at det netop er det mirakel - vi vender straks tilbage til det - som giver grundlag for, eller lad os snarere sige, som konstituerer den proustske fortællings »uendelige bygningsværk«.

51. III, pp. 874-876, kursiveret af os. Allerede i Swann - i forbindelse med $\mathrm{M}^{\text {me }}$ Swanns toiletter og den smukke ramme om hendes liv - talte Proust om »solidariteten, som de forskellige dele af en erindring har med hinanden, og som vores hukommelse holder i ligevægt i en sammenføjning, hvor vi ikke har lov til hverken at udskille eller nægte noget«, I, p. 426, vores kursiveringer. 
Det kan synes misvisende - som for at kunne nyde en kunstig symmetri - at bruge navnet "metonymi« for denne solidaritet mellem erindringer, som ikke indebærer nogen substitutionseffekt, og som således ikke på nogen måde kan indgå i kategorien af troper, der studeres af retorikken. Det ville sikkert være tilstrækkeligt at svare, at det er den semantiske relations natur, det drejer sig om her, og ikke figurens form, og at erindre om, at Proust selv har givet eksemplet på et sådant misbrug ved at døbe metaforen en figur, som hos ham oftest kun er en explicit sammenligning uden substitution; på den måde er effekterne af den afsmitning, vi har talt om, på kontiguitetsaksen næsten ækvivalent med det, som de proustske "metaforer« er på analogiaksen - og er således i forhold til den strikte metonymi det, som de proustske metaforer er i forhold til den klassiske metafor. Men det skal dertil siges, at påkaldelsen gennem kontiguitet undertiden hos Proust er ført hen til grænserne af substitutionen. Ullmann henviser meget passende til en sætning fra Swann: "Denne dunkle friskhed i mit værelse ... tilbød min forestillingsevne det totale billede af sommeren. ${ }^{52}$ Signalsansning bliver ret hurtigt hos Proust til en slags ækvivalent til konteksten, som den er forbundet med, ligesom Vinteuils »lille frase« for Swann og Odette er blevet »som deres kærligheds nationalhymne«: $:^{33}$ så at sige deres emblem. Og man skal lægge mærke til, at de eksempler på »naturlige« metaforer, som der henvises til i le Temps retrouvé, i realiteten typisk er synekdoniske substitutioner: »Naturen ... var den ikke i sig selv begyndelse til kunst, den som ofte kun havde tilladt mig at kende en tings skønhed i en anden, middagsstunden i Combray kun i lyden fra dens kirkeklokker, morgenerne i Doncières kun i hikkelydene fra vores varmtvandsanlæg?« Endelig spiller fænomenet metonymisk forskydning, der er velkendt fra psykoanalysen, ofte en vigtig rolle i selve den proustske fortællings tematik. Man ved, hvorledes Marcels beundring for Bergotte drager fordel af hans kærlighed til Gilberte, eller hvordan netop denne kærlighed i sig selv overføres på den unge piges forældre, deres navn, deres hus, deres kvarter; eller videre, hvordan hans lidenskab for Odette, som bor i Rue la Pérouse, gør Swann til en stamgæst på restauranten af samme navn: således ser man her homonymi oven på metonymi. Af denne art er begærets »retorik«. Mere massivt er det seksuelle tema oprindeligt, i Combray, forbundet med alkoholtemaet i kraft af en simpel temporal rækkefølge; hver gang bedstefaderen, til stor fortvivlelse for sin hustru, lader sig rive med af at drikke cognac, søger Marcel tilflugt $\mathrm{i}$ »det lille kabinet, der lugter af iris«, det foretrukne sted for hans syndige fornøjelser; følgelig forsvinder den bevidste seksuelle syndefuldhed næsten fuldstændigt

52. Loc.cit.; cf. I, p. 83.

53. I, p. 218. 
hos helten, idet den erstattes af (maskeres som) syndefuldheden forbundet med alkoholudskejelserne, der er motiveret af hans sygdom, men som er så smertelig for hans bedstemor, der åbenlyst er et substitut (også det af metaforisk-metonymisk karakter) for hans mor: smerten og syndefuldheden, som fremtræder helt ude af proportioner med hinanden, hvis ikke man opfatter denne »svagheds« emblematiske værdi. ${ }^{54}$

Der er således hos Proust en meget hyppig skjult forbindelse mellem den metaforiske og den metonymiske relation, dels i den forstand, at den første lægger sig til den anden som en slags overdeterminerende fortolkning, dels i den forstand, at den sidstnævnte i oplevelserne af "ufrivillig erindring" afløser den førstnævnte for derved at forøge virkningen og indholdet. Denne situation forekommer mig at kalde på to bemærkninger, hvor den ene befinder sig på de stilistiske mikrostrukturers niveau og den anden på den narrative makrostrukturs niveau.

Forste bemcerkning: man genkaldte sig med det samme, at de eksempler, som der blev henvist til umiddelbart efter den berømte sætning til ære for metaforen, snarere illustrerede det metonymiske princip. Men det er nødvendigt nu at kigge nærmere på selve denne sætning. »Man kan, «skriver Proust "i en beskrivelse lade genstandene, som optræder på det beskrevne sted, følge efter hinanden i det uendelige, sandheden begynder først i det øjeblik, hvor forfatteren tager to forskellige objekter, viser deres relation - svarende i kunstens verden til den, som den unikke kausallovsmæssige relation er i videnskabens verden - og indeslutter dem en smuk stils nødvendighedskæder; på samme måde som når han, ligesom livet, idet han sammenkæder en kvalitet, som er fælles for to sanseindtryk, frigør deres fælles essens, idet han, for at unddrage dem tidens vilkårligheder, forener dem i en metafor." Det siger sig selv, at "relationen" som skal vises mellem »to genstande« er analogirelationen, som frigør deres "fælles essens«. Hvad der er mindre evident, men hvad der forekommer næsten uomgængeligt for kohærensen i udsagnet, er, at disse to genstande er del af den samling af genstande, som "optræder" (sammen) på det sted, der skal beskrives: anderledes sagt, at den metaforiske relation etableres mellem to termer, som allerede er forbundet gennem en rum-tidslig nærhedsrelation. Således (og kun således) kan man

54. Se især I, pp. 12, 497, og 651-2. Dette syndstema dukker også op i II, pp. 171-2, hvor den berusede Marcel i et spejl ser sit "fæle" spejlbillede, billedet på et "gyseligt jeg». Men den stærkeste markering af forbindelsen mellem den alkoholiske "udskejelse» og den seksuelle (ødipale) syndefuldhed er uden tvivl i den sætning, hvor hans mors bekymrede mine - idet Marcel over for hende erklærer sin intention om at gifte sig med Albertine - bliver sammenlignet med »den mine, som hun havde haft første gang i Combray, da hun havde bøjet sig for at tilbringe natten hos mig, denne mine, som i det øjeblik i usædvanlig grad lignede den, som min bedstemor havde, da hun gav mig lov til at drikke cognac«, II, p. 1131. 
forklare, at »den smukke stil«, d.v.s. den metaforiske stil, her skal være karakteriseret af en sammenkædnings- og nødvendighedseffekt ("nødvendighedskæder«). Skriftens uforgængelige soliditet, som Proust her synes at søge den magiske formular for (»kun metaforen kan give en slags evighed til stilen«, siger han i sin artikel om Flaubert ${ }^{55}$ ), kan ikke frembringes af den simple horisontale forbindelse, som er etableret i kraft af den metonymiske kæde; men man ser heller ikke, hvordan den metaforiske relations simple vertikale forbindelse skulle kunne levere en sådan. Kun ved at lade den ene skære den anden kan man friholde beskrivelsens genstand - og selve beskrivelsen - fra »tidens vilkårligheder«, d.v.s. fra enhver kontingens; kun krydsningen af en metonymisk tråd og en metaforisk kæde sikrer kohærens, tekstens "nødvendige« sammenhæng. Denne metafor er mere end halvvejs antydet af den metafor, som Proust bruger: »kæder«, led, masker, vævning. Men det billede, hvortil Proust selv helst vender tilbage, er af mere substantiel karakter: det er motivet "sammensmeltning«, det homogene. Det, som for ham udgør den »absolutte skønhed«, det er, skal vi huske,

»en art sammensmeltning, transparent enhed, hvor alle tingene, idet de taber deres første karakter af ting, er kommet dertil, hvor de er placeret ved siden af hinanden i en slags orden, gennemtrængt af det samme lys, hvor de ses inde i hinanden, uden et eneste ord, som forbliver udenfor, som forbliver genstridigt over for denne assimilation ... Jeg formoder, at det er det, som man kalder Mesterlak«. ${ }^{56}$

Man ser, at endog kvaliteten i stilen afhænger af en "assimilation«, der etableres mellem genstande, som er til stede samtidig, mellem »ting«, som for at tabe »deres første karakter af ting«, d.v.s. deres vilkårlighed og deres spredthed - må reflektere hinanden indbyrdes og opsuges i hinanden, på én gang "placeret ved siden af hinanden« (kontiguitet) og »set inde i hinanden« (analogi). Hvis man - som Roman Jakobson foreslår $\operatorname{det}^{57}$ - ønsker at beskrive den metonymiske linie som den egentlig prosaiske dimension i dis-

55. Contre Sainte-Beuve, Paris 1971, p. 586. (Vi kursiverer.)

56. Correspondance générale, Paris 1930-36, II, p. 86. Lad os også erindre om denne anden formulering af det samme ideal: »I Flauberts stil, f.eks., er alle dele af virkeligheden omdannet til den samme substans, til vældige overflader, med ensartet glans. Ingen urenhed er blevet tilbage. Overfladerne er blevet reflekterende. Alle ting pudser sig deri, men gennem refleks uden derved at ændre den ensartede substans. Alt det, som var forskelligt, er blevet omdannet og opsuget«, Contre Sainte-Beuve, p. 269. Samme effekt af substansforening, denne gang i maleriet, finder man i denne variant i Jeunes Filles en fleurs: "Ligesom på Elstirs billeder ... hvor det mest moderne hus i Chartres, i kraft af selve det lys, som gennemtrænger det, i kraft af den samme »impression«, er blevet er blevet ét med katedralen ...«, I, p. 968, vi kursiverer.

57. Essais de linguistique générale, pp. 66-7. 
kursen, og den metaforiske linie som den poetiske dimension, så bør man betragte den proustske skrift som det mest vidtgående forsøg i retning af denne blandingstilstand, som det, idet den fuldt ud overtager og aktiverer sprogets to akser, sikkert ville være latterligt at kalde "prosadigt« eller "poetisk prosa", og som absolut og i termens fulde betydning ville konstituere Teksten.

Anden bemcerkning: Hvis man måler betydningen af den metonymiske afsmitning i det proustske forestillingssarbejde og især i oplevelsen af den ufrivillige erindring, bliver man ledt til lidt at forskyde det uundgåelige spørgsmål, som giver genlyd i Maurice Blanchots le Livre à venir ${ }^{58}$ hvordan har Proust bevæget sig fra sin »oprindelige plan, som var at skrive en roman af poetiske øjeblikke« til den (næsten) kontinuerte fortælling, som $\dot{A}$ la recherche du temps perdu er? Blanchot svarede straks, at essensen af disse øjeblikke »er ikke at være punktuelle«, og måske ved vi nu bedre hvorfor. I virkeligheden har Prousts plan aldrig været at skrive en bog bestående af en samling poetiske ekstaser. Allerede Jean Santeuil er noget andet, og selv det berømte afsnit, hvor fortælleren, idet han på en i den grad bydende måde træder i stedet for sin helt (og hele Recherche ligger allerede i denne bevægelse), bekræfter kun at have skrevet "når en fortid pludselig genopstod i en lugt, i et syn, som fik den til at bryde ud, og oven på hvilken forestillingen bævede, og når denne glæde gav mig inspiration «, ${ }^{59}$ selv denne side giver ikke ret til at dømme således: den fortid, som er "genopstået« ved et møde af sansefornemmelser, er ikke så "punktuel« som dette møde i sig selv, og det er nok med en enkelt - og ubetydelig - reminiscens, takket være den metonymiske udstråling som ledsager den, for at udløse en anamnesebevægelse af en usammenlignelig styrke. For det er, mere præcist, hvad der foregår i $\dot{A} l a$ Recherche du temps perdu.

Der i realiteten et meget kraftigt snit i første del af Swann (»Combray«), mellem det første kapitel, som næsten udelukkende er viet til denne oprindelige og besættende scene, som Proust kalder »scenen og dramaet omkring min gåen i seng «, en scene, der for længst i fortællerens erindring var blevet ligesom det eneste minde fra Combray, som aldrig havde sænket sig i glemsel, en ubevagelig og på sin vis "punktuel« scene, hvori narrationen lukker sig inde og begraver sig som uden håb om nogensinde at kunne løsrive sig og det andet kapitel, hvor - i den repetitive besættelses og "fixeringens" vertikale Combray (»lysende pan aftegnet midt i utydelige skygger« gengivet i den lille salon og i spisesalen, hvor man modtager hr. Swann, ved den

58. "L'Experience de Proust«, pp. 18-34.

59. Proust: Jean Santeuil, Paris 1971, p. 401. 
"forhadte« trappe, i værelset hvor Marcel desperat venter på det moderlige kys) med dets udstrakte rum, dets »to sider", dets skiftende spadsereture barndomsgeografiens og familietidsregningens horisontale Combray endelig substitueres, udgangspunkt for og antænding af den sande narrative bevægelse. Dette snit, dette register- og systemskift uden hvilket den proustske roman simpelhen ikke ville finde sted, det er åbenlyst Combrays "genopstandelse« gennem den ufrivillige erindring, d.v.s. uløseligt gennem »en analogis mirakel og gennem det andet mirakel, som ser (som lader) en hel barndom - »by og haver«, rum og tid - i forlængelse heraf, "gennem erindringernes association«, et helt liv (og nogle andre), opstå af en kop te. Denne paradoksale effekt af erindringsresten, som er på én gang fastholdelse og impuls, brat standsning, traumatisk (skønt »frydefuld«) åbning til den levede tid (det er den metaforiske ekstase) og en med det samme ustoppelig og kontinuert udstrømning af den "genfundne«tid, d.v.s. genlevet (det er den metonymiske afsmitning), viste sig allerede på en afgørende måde i en sætning, der tjener som efterskrift til Jean Santeuil: "Kan jeg kalde denne bog en roman? Den er måske mindre og dog mere, selve essensen af mit liv, opfanget, uden at noget er blandet i, i disse brudfyldte øjeblikke, hvori det forløber « ${ }^{60}$ Nutidens sår, fortidens udstrømning, det vil også (eftersom »tiderne« også er former) sige: talens ophør og fortællingens fødsel. Uden metafor, siger Proust (næsten), ingen sande erindringer; vi tilføjer for ham (og for alle): uden metonymi, ingen sammenkædning af erindringer, ingen historie, ingen roman. Thi det er metaforen, som genfinder den tabte Tid, men det er metonymien, som genopliver den, og som på ny sætter den i gang: som giver den klarhed over sig selv og dens sande »essens«, som er dens egen flugt og dens egen Recherche. Her og kun her - ved hjælp af metaforen, men $i$ metonymien - begynder Fortællingen. ${ }^{61}$

\section{Oversat af Jørgen Holmgaard fra »Métonymie chez Proust", in Gérard Genette: Figures III, Paris 1972.}

60. Op. cit., p. 181. (Vi kursiverer.)

61. Det er Jean Pommier, som allerede i 1939 bemærkede kontiguitetens rolle i visse proustske metaforer: "Det, som synes at styre relationen mellem sansningerne, det er kontiguiteten af korresponderende egenskaber i genstanden. Taget afstøder ikke sine skifre uden duerne, som hviler på dem, som hviler der den ene ved siden af den anden: deraf kommer det, at deres kurren aftegner "en horisontal linie«, til forskel fra hanen, hvis galen stiger op mod himlen. Når fortælleren anvender epiteterne »oval og forgyldt« ikke på den lille klokke, men på dens klemten, laver han en hypallage. Hvorfor er lyden af klokkerne forbundet med smagen af syltetøj? For at blive forsinket »som en hveps« på bordet i Combray. For så vidt angår de nye mure, forlænger deres "sønderrivende« skrig uden tvivl de skrig, som saven, hvoraf de bærer mærke, har måttet fravriste stenene«, La Mystique de Marcel Proust (org. 1939), Paris 1968, p. 54. 